\title{
Temporal variation in the prevalence of the crayfish plague pathogen, Aphanomyces astaci, in three Czech spiny-cheek crayfish populations
}

\author{
K. Matasová(1), E. Kozubíková(1), J. Svoboda ${ }^{(1)}$, V. Jarošík ${ }^{(1,2)}$, A. PetruseK ${ }^{(1)}$ \\ Received January 15, 2011 \\ Revised April 7, 2011 \\ Accepted April 12, 2011
}

\section{ABSTRACT}

Key-words:

Orconectes

limosus, oomycete, infection prevalence, molecular detection, crayfish plague

\begin{abstract}
North American crayfish species are natural hosts of the crayfish plague pathogen Aphanomyces astaci. The spiny-cheek crayfish Orconectes limosus, widespread in Central Europe, is the main reservoir of $A$. astaci in Czech Republic. We tested if there are temporal changes in the prevalence of infected individuals (i.e., the proportion of individuals in which the pathogen is detected) in spiny-cheek crayfish populations. Crayfish from three populations shown previously to be infected to different extents (high, intermediate and low), were repeatedly sampled in different years (2004-2010) and seasons. The presence of $A$. astaci in the soft abdominal crayfish cuticle was tested by specific amplification of the pathogen DNA. There was no substantial temporal variation in pathogen prevalence in the highly and very lowly infected populations. However, a significant long-term as well as seasonal decrease was found in the intermediately infected population. This decline could be related to a decrease in population density over the studied years, and to crayfish seasonal moulting, respectively. A reliable estimate of pathogen prevalence in American crayfish populations thus requires repeated monitoring over years, preferably during the same season before the main period of crayfish moulting.
\end{abstract}

\section{RÉSUMÉ}

Variation temporelle de la prévalence de l'agent de la peste de l'écrevisse, Aphanomyces astaci, dans trois populations tchèques d'écrevisses américaines

\begin{abstract}
Mots-clés : Orconectes limosus, oomycète, prevalence d'infection,
\end{abstract}

\begin{abstract}
Les espèces d'écrevisses nord-américaines sont des hôtes naturels de l'agent pathogène de la peste de l'écrevisse, Aphanomyces astaci. L'écrevisse américaine, Orconectes limosus, très répandue en Europe centrale, est le réservoir principal d'A. astaci en République tchéque. Nous avons recherché s'il y a des changements de prévalence dans le temps (i.e. la proportion d'individus pour laquelle le pathogène est détecté) dans des populations de l'écrevisse américaine. Les écrevisses de trois populations connues pour être infectées à différents niveaux (fort, moyen et bas) ont été échantillonnées à plusieurs reprises différentes années (2004-2010) et saisons. La présence d'A. astaci dans
\end{abstract}

(1) Department of Ecology, Faculty of Science, Charles University in Prague, Viničná 7, Prague 2, 12844, Czech Republic, evikkk@post.cz

(2) Department of Invasion Ecology, Institute of Botany, Academy of Sciences of the Czech Republic, 25243 Průhonice, Czech Republic 
détection moléculaire, peste de l'écrevisse la cuticule abdominale souple de l'écrevisse a été recherchée par amplification spécifique de I'ADN du pathogène. II n'y a pas de variation importante dans le temps dans la prévalence du pathogène dans les populations très ou très faiblement infestées. Toutefois, une décroissance significative à long terme comme saisonnière a été trouvée dans la population à niveau d'infestation moyen. Cette décroissance pourrait être corrélée à une décroissance de la densité de population au cours des années d'étude et à la mue saisonnière. Une estimation fiable de la prévalence du pathogène dans les populations d'écrevisses américaines nécessite un suivi régulier sur plusieurs années, de préférence à la même saison avant la période principale de mue de l'écrevisse.

\section{INTRODUCTION}

Invasive North American crayfish species (hereafter "American"), in particular those intentionally introduced for aquaculture purposes in the 19th and 20th centuries (the spiny-cheek crayfish Orconectes limosus, the signal crayfish Pacifastacus leniusculus, and the red swamp crayfish Procambarus clarkii), are widespread in Europe (Souty-Grosset et al., 2006; Holdich et al., 2009). One important negative impact of their invasions is that they often outcompete indigenous European crayfish and permanently occupy their habitats (Westman and Savolainen, 2001). Apart from a wide range of advantageous competitive abilities (Lindqvist and Huner, 1999), all three of the most widespread American crayfish species in Europe have been confirmed to host and spread the oomycete Aphanomyces astaci (Persson and Söderhäll, 1983; Vey et al., 1983; Diéguez-Uribeondo and Söderhäll, 1993), the causative agent of crayfish plague. This oomycete causes mass mortalities of European crayfish, and belongs among the worst invasive species on both European and global scales (Lowe et al., 2004; Vilà et al., 2009).

A. astaci is highly adapted to life in close association with crayfish. It does not seem to be able to survive without crayfish hosts for longer periods of time (Söderhäll and Cerenius, 1999). Dispersal stages in the $A$. astaci life cycle are short-lived zoospores mediating the transmission of infection to other host individuals (Cerenius et al., 1988), no durable long-lived spores are known (Matthews and Reynolds, 1990). The immune system of American crayfish is well adapted to coping with the presence of this pathogen (Alderman, 1996). However, European species show only a very weak immune response to the parasite, and $A$. astaci usually decimates whole populations of susceptible species. In cases of such mass mortalities, the disease disappears from the impacted locality if zoospores cannot find a suitable substrate for growth (Söderhäll and Cerenius, 1999).

Despite previous assumptions (e.g., Cerenius et al., 2003), not all American crayfish individuals seem to be infected with $A$. astaci. Therefore, populations may vary in the likelihood of pathogen transmission to indigenous crayfish (Nylund and Westmann, 2000; Kozubíková et al. , 2009). However, studies dealing with the prevalence of individuals infected with $A$. astaci in potential carrier populations have only recently become common, when molecular methods allowed more reliable pathogen detection. Before the use of DNA-based methods, Nylund and Westman $(1983,2000)$ assessed the prevalence of the pathogen in some Finnish signal crayfish populations using the presence of melanised spots in the crayfish cuticle. The authors analysed the proportions of crayfish carrying such spots over a 14-year period, and observed substantial interannual variation in addition to long-term trends of decreases and increases. Their later study (Nylund and Westman, 2000) remains the only one dealing with long-term changes in the prevalence of the crayfish plague pathogen within American crayfish populations. Unfortunately, visible melanisation does not seem to be a reliable indicator of the presence of $A$. astaci, at least in some crayfish species (Kozubíková et al., 2009; Aquiloni et al., 2011).

Later studies have employed more reliable molecular detection methods based on speciesspecific amplification of parasite DNA to investigate the infection status of American crayfish 
populations. Oidtmann et al. (2006) first established a molecular method suitable for the detection of $A$. astaci in American crayfish. Subsequently, DNA-based detection was employed on all three of the most important American crayfish invaders in Europe (the signal crayfish: Johnsen et al., 2007; Dunn et al., 2009; Hochwimmer et al., 2009; Skov et al., 2011; the spiny-cheek crayfish: Schulz et al., 2006; Kozubíková et al., 2006, 2008, 2010; and the red swamp crayfish: Aquiloni et al., 2011). The above-mentioned studies were mostly limited in geographical coverage and the number of analysed populations. Their results suggest that substantial variation in the prevalence of infected individuals among populations exists. However, only the study by Kozubíková et al. (2009), which focused on larger-scale screening of the parasite prevalence in American crayfish populations in Czechia, repeated sampling of at least some populations in different seasons or years. Although the results suggested that the parasite prevalence might be relatively stable in time, only a few such replicated samplings were available.

Given the fact that the crayfish plague pathogen resides in the cuticle of American crayfish, there is a feasible alternative scenario to temporal stability of pathogen prevalence in carrier populations. The detectability of pathogen presence may vary seasonally in association with moulting, as moulting may lead to the removal of parasites, symbionts and epibionts inhabiting crayfish cuticle along with the exuviae (e.g., Jones and Lester, 1996; Ďuriš et al., 2007). If this is the case for $A$. astaci, the observed prevalence may decrease in periods when moulting is frequent, and increase when most crayfish individuals have spent a substantial amount of time since the last moult.

The aim of this study was to extend our knowledge on long-term temporal changes in the prevalence (or detectability) of $A$. astaci in American crayfish populations, and to test the two above-mentioned scenarios on seasonal patterns of prevalence. We chose three Czech populations of the spiny-cheek crayfish, which is the most common American crayfish in the country (Petrusek et al., 2006). These populations were found to differ in $A$. astaci prevalence in the period 2004-2006 (Kozubíková et al., 2009). We re-sampled them repeatedly in different seasons during the years 2007-2010, and analysed crayfish for the presence of $A$. astaci with the same molecular method as in Kozubíková et al. (2009). Adult spiny-cheek crayfish moult once or twice a year (Holdich and Black, 2007). The time of moulting is influenced by the water temperature, condition of the individual and the egg- and juvenile-carrying period of females (Burič et al., 2010a, 2010b). Moulting can occur throughout the whole season but peaks in summer (Holdich and Black, 2007). Therefore, we hypothesised that the ratio of individuals testing positive for $A$. astaci may decrease in autumn.

\section{MATERIAL AND METHODS}

\section{> CRAYFISH SAMPLES}

Three populations of spiny-cheek crayfish were chosen based on our previous results (Kozubíková et al., 2009) and according to their suitability for repeated sampling (dense crayfish populations, easily accessible localities). Crayfish were sampled from a small pond in Smečno (Central Bohemia, 50 $11^{\prime} \mathrm{N}, 14^{\circ} 02^{\prime} \mathrm{E}$ ), a stream Pšovka (Central Bohemia, $50^{\circ} 23^{\prime} \mathrm{N}, 14^{\circ} 33^{\prime} \mathrm{E}$ ), and a flooded quarry in Starý Klíčov (West Bohemia, 49 $24^{\prime} \mathrm{N}$, $\left.12^{\circ} 57^{\prime} \mathrm{E}\right)$. Previously analysed crayfish individuals from these localities tested positive in $98 \%, 54 \%$ and $3 \%$ of cases, respectively, suggesting high, intermediate and very low prevalence of infection carriers in the populations. The results from previous samplings from 2004 to 2006 (Kozubíková et al., 2009) were also included in this study.

The presence of $A$. astaci was confirmed by sequencing the amplified fragment of the internal transcribed spacer (ITS) of the pathogen rDNA after Oidtmann et al. (2006) in the populations from Smečno (Kozubíková et al., 2009) and Pšovka (Kozubíková, unpublished data). However, such proof is missing for Starý Klíčov (Kozubíková et al., 2009) and the molecular detection methods indicated only trace amounts of the pathogen DNA. Therefore, false positive results might have been involved, and it cannot be excluded that none of previously analysed 


\section{Table I}

Results of molecular detection of Aphanomyces astaci in three Czech populations of Orconectes limosus in repeated samplings during the period 2004 to 2010. Numbers of analysed individuals and numbers and percentages of those with positive detection of the pathogen are given.

\section{Tableau}

Résultats de détection moléculaire d'Aphanomyces astaci dans trois populations tchèques d'Orconectes limosus dans plusieurs échantillons au cours de la période 2004 à 2010. Les nombres d'individus analysés et nombres et pourcentages de ceux à détection positive du pathogène sont indiqués.

\begin{tabular}{|c|c|c|}
\hline Sampling date & N & Positive \\
\hline \multicolumn{3}{|l|}{ Smečno (pond) } \\
\hline 9 Apr. 2006* & 20 & 19 (95\%) \\
\hline 3 Nov. $2006^{*}$ & 20 & 20 (100\%) \\
\hline 5 Nov. 2007 & 13 & $11(85 \%)$ \\
\hline 14 May 2008 & 12 & 12 (100\%) \\
\hline 22 Aug. 2008 & 10 & 9 (90\%) \\
\hline 28 Nov. 2008 & 6 & $5(83 \%)$ \\
\hline 30 Apr. 2009 & 15 & 15 (100\%) \\
\hline 16 Sep. 2009 & 2 & $2(100 \%)$ \\
\hline \multicolumn{3}{|l|}{ Pšovka (stream) } \\
\hline 13 Sep. 2004 & 10 & $6(60 \%)$ \\
\hline 4 Jun. $2005^{\star}$ & 18 & $9(50 \%)$ \\
\hline 15 Oct. 2007 & 20 & $4(20 \%)$ \\
\hline 19 May 2008 & 20 & $7(35 \%)$ \\
\hline 10 Aug. 2008 & 20 & $5(25 \%)$ \\
\hline 29 Apr. 2009 & 20 & $10(50 \%)$ \\
\hline 14 Aug. 2009 & 20 & 0 \\
\hline 2 Nov. 2009 & 10 & $1(10 \%)$ \\
\hline 7 Nov. 2010 & 21 & 0 \\
\hline \multicolumn{3}{|c|}{ Starý Klíčov (quarry) } \\
\hline 23 Oct. 2005 & 20 & 0 \\
\hline 31 Mar. 2006* & 40 & $1(3 \%)$ \\
\hline 20 May 2008 & 10 & 0 \\
\hline 1 Oct. 2008 & 22 & 0 \\
\hline 24 Apr. 2009 & 20 & 0 \\
\hline 27 Aug. 2009 & 20 & 0 \\
\hline
\end{tabular}

* Results included in Kozubíková et al. (2009).

individuals from this population was actually infected by $A$. astaci (see discussion for more details).

Crayfish were randomly sampled in potential shelters by hand searching (Smečno, Pšovka) or scuba diving (Starý Klíčov), with the same search intensity at each visit. Apart from two cases when the sampling was not very successful (two and six caught individuals, respectively), we analysed at least ten crayfish per sampling. Crayfish were obtained from 2007 to 2010 (Table I), but most of the samples were from the years 2008 and 2009 when we intended to sample all three populations three times a year in different seasons: in spring (March to May), summer (June to August) and autumn (September to November). However, as the sampling success was sometimes very low, the intended sampling design for the years 2008 and 2009 could not be fully completed (see Table I). Crayfish were stored at $-80{ }^{\circ} \mathrm{C}$ before further processing. Each individual was kept in a separate plastic bag during sampling and storage to avoid cross-contamination.

\section{> DNA EXTRACTION AND MOLECULAR DETECTION OF A. ASTACI}

To obtain comparable data with our previous results from the years 2004 to 2006 included in this study, we used exactly the same approach for detection of $A$. astaci as 
in Kozubíková et al. (2009). Up to $50 \mathrm{mg}$ of soft abdominal cuticle (in crayfish with body size below $5 \mathrm{~cm}$, part of the telson was also included) was dissected with sterile tools, and homogenised after flash freezing in liquid nitrogen. Total genomic DNA was extracted using a DNeasy Blood \& Tissue Kit (Qiagen, Hilden, Germany). A presumably A. astaci-specific amplification of the ITS fragment, using the semi-nested PCR protocol after Oidtmann et al. (2006), was used to detect the parasite DNA in samples. The first PCR was performed with primers " 42 " and "640". The reaction mixture, potentially containing a ca. 550 base pair (bp) long PCR product, was then used as a template for the second PCR with primers " 525 " and "640", amplifying a 115 bp DNA fragment. PCR products were visualised by agarose electrophoresis. Bands at the same position as those obtained by amplification of a positive control (DNA isolated from a laboratory culture of $A$. astaci of the strain M96/1, genetic group B; Oidtmann et al., 1999) were considered as confirmation of the parasite presence in the analysed crayfish individual. A detailed protocol and discussion of the potential limitations of this method are given in Kozubíková et al. (2009).

\section{> DATA ANALYSIS}

Proportions of individuals in which the pathogen was detected were examined by analyses of covariance (ANCOVAs). Prevalence, i.e., the proportion of infected individuals in each sample, was the response variable. The factor "locality" had three levels: Smečno, Pšovka, and Starý Klíčov. Time, expressed in days since the beginning of observations, or since the spring equinox of each year of the sampling period, respectively, was the covariate. The analysis was first done for long-term trend, i.e., focusing on changes over the entire period from 2004 to 2010 , and then repeated for seasonal trend, i.e., focusing on differences between samples collected in different periods of the year.

Prevalence was analysed by specifying binomial errors and the logit link function, with data for this response variable stored for each sample in two vectors: one to identify the number of infected individuals, the second being the number of individuals in which the pathogen was not detected. To prevent the logits of infected individuals estimated from small samples of having undue influence, logits were weighted by the total number of individuals in each sample. Overdispersion of binomial errors was checked by comparing residual deviance with residual degrees of freedom, and treated by quasi error structure for binomial errors. Calculations were done in S-Plus v. 8 (TIBCO Software, Palo Alto, USA) following Crawley (2002, pp. 532-536).

The modelling started with fitting a model that contained all possible interactions among the factor and covariate. The parameters of this model were inspected, and the least significant term was removed in a deletion test, provided that its deletion caused a non-significant increase in deviance. Deletion tests were repeated until minimal adequate models (MAMs) were established. In MAMs, all non-significant parameters were removed, and all the remaining parameters were significantly $(P<0.05)$ different from zero and from each other (Crawley, 1993).

\section{RESULTS}

In total, we obtained data from 389 spiny-cheek crayfish individuals from 18 samplings (Table I). Ninety-eight individuals were from the pond in Smečno, 159 from the stream Pšovka, and 132 from the flooded quarry in Starý Klíčov. Proportions of individuals that tested positive for each particular sampling are given in Table I, and both long-term and seasonal trends are shown in Figure 1. As expected, the among-population differences in the proportion of positive individuals were highly significant $(F=74.26$; $\mathrm{df}=2,20 ; P<0.001$ and $F=79.92$; $\mathrm{df}=2,20 ; P<0.001$ for long-term and seasonal trend, respectively).

No increasing or decreasing trend in the prevalence of infected crayfish was observed in the populations from Smečno and Starý Klíčov $(F=0.32$; $\mathrm{df}=2,17$; NS and $F=1.15$; $\mathrm{df}=2,17$; NS; deletion test on a change in prevalence for long-term and seasonal trends, respectively). 

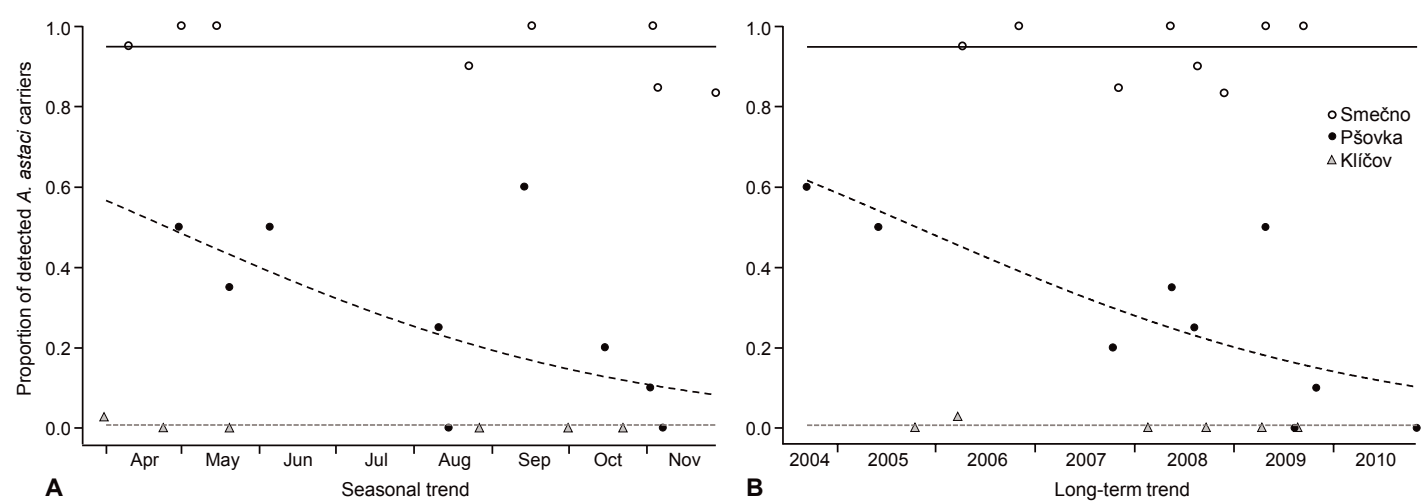

Figure 1

Minimal adequate models of ANCOVA for long-term (A) and seasonal (B) trends in the prevalence of the crayfish plague pathogen Aphanomyces astaci in the three studied Czech populations of the spinycheek crayfish Orconectes limosus.

Figure 1

Modèles d'ANCOVA pour les tendances à long terme $(A)$ et saisonnière $(B)$ de la prévalence du pathogène de la peste de l'écrevisse Aphanomyces astaci dans les trois populations tchèques étudiées d'écrevisse américaine Orconectes limosus.

We did not detect any positive individual in any sample from Starý Klíčov collected between May 2008 and August 2009. On the contrary, 95\% of all tested crayfish from Smečno were positive. Thus, the prevalence of positive individuals remained very high in all sampled years, and no significant temporal variation was found in this population.

In the population from the stream Pšovka, the prevalence of positive individuals varied among samplings from 0 to $50 \%$ (60\% if data from Kozubíková et al., 2009 are included). Significant decreases in this proportion (Figure 1 ) were found on both the long-term $(F=10.53$; $\mathrm{df}=1$, 19; $P<0.01)$ as well as seasonal $(F=9.30 ; \mathrm{df}=1,19 ; P<0.01)$ scales.

\section{DISCUSSION}

Our results show that at least in some populations of American crayfish, the prevalence of individuals detected as carriers of $A$. astaci considerably varies over time, while in other populations it may not significantly change for years. This finding is important, as it stresses the need for careful interpretations of results obtained from pathogen detection studies.

Since we intended to compare our new data with previous results, we followed the same semi-nested PCR method as in Kozubíková et al. (2009) to test for the presence of $A$. astaci in crayfish. Although other protocols are currently recommended (Oidtmann et al., 2006; Vrålstad et al., 2009), extensive testing on field-collected crayfish individuals has shown that the semi-nested PCR provides, in comparison with other methods, sufficient sensitivity and specificity for our purpose (Kozubíková et al., unpublished data). Nevertheless, the semi-nested PCR may exceptionally produce false positive results with non- $A$. astaci DNA, as documented by sequencing in a single case by Kozubíková et al. (2009). This protocol also seems to be less sensitive than a more-advanced real-time PCR detection method after Vrålstad et al. (2009) (Kozubíková et al., unpublished data). Furthermore, as we tested only a few individuals from each population, dissected only part of the crayfish body, and used only part of the DNA isolate in PCR, infection might have been missed in some individuals. Our results thus might underestimate the proportion of infection carriers in a population at a given time. However, this systematic error is presumably the same for all samplings, so it should not influence the conclusions of this study.

The patterns of prevalence in the studied localities supported both proposed scenarios of temporal changes, a seasonal and long-term variation as well as the steady state. 
The high- and low-prevalence populations remained so during the whole study period (2005/6-2009) and throughout the seasons. Pond in Smečno as well as flooded quarry in Starý Klíčov are small standing water bodies less than one hectare in size. Their crayfish populations are dense and closed, with no possibilities for migration. In the highly infected population, this might support the homogenous spread of parasite zoospores among crayfish, and thus prevent temporal fluctuations in the prevalence of infected individuals.

In the crayfish population from Starý Klíčov, we did not detect $A$. astaci in any samples from 2008 and 2009, and only one individual out of 40 analysed from March 2006 was detected as infected in the previous study (Kozubíková et al., 2009). As already suggested by Kozubíková et al. (2009), this one exceptional case might have been a false positive result caused by non- $A$. astaci DNA in the semi-nested PCR. The band on the agarose gel was faint, which Oidtmann et al. (2006) recommended to consider with care, and could not be sequenced to verify it as $A$. astaci DNA. Furthermore, it was not supported with the real-time PCR assay after Vrålstad et al. (2009) (Kozubíková, unpublished data). However, real-time PCR suggested the presence of a very low amount of parasite DNA (agent level A2, after Vrålstad et al., 2009) in one additional DNA isolate from the previous study (Kozubíková, unpublished data). Although we cannot completely exclude later laboratory contamination of that particular DNA isolate, we also cannot exclude the presence of $A$. astaci in some crayfish from this population with agent levels undetectable with the semi-nested PCR. While it remains unclear whether $A$. astaci is present at this locality, we can conclude that the infection status did not increase between 2005 and 2009. Even if the parasite is absent from the population at present, it may spread there from another source in the future.

Unlike in closed standing waters, spiny-cheek crayfish in the stream Pšovka can migrate along its course and into and out of two connected fishponds. Migrations between areas with high and low infection prevalence in an intermediately infected population might explain the variation in the proportion of crayfish that tested positive among different samplings. However, the observed temporal pattern does not seem to be accidental, as we observed a clear decrease of prevalence in Pšovka on both the long-term and seasonal scales.

This long-term decrease in the percentage of individuals carrying a detectable infection could be linked with a possible decrease in population density. Crayfish catch per unit effort declined in Pšovka over the years of study (Petrusek, pers. observations). At lower population densities, crayfish tend to be farther away from each other, which may lead to decreased transmission of the pathogen via zoospores (as suggested by Kozubíková et al., 2009).

The significant seasonal variation observed in Pšovka supports the hypothesis that pathogen detectability may decrease after moulting, which helps crayfish get rid of parasites or commensals living inside or on the surface of their cuticle. A. astaci is apparently adapted to moulting of the host crayfish. However, it is not known whether some part of the parasite mycelium remains in the moulted crayfish or whether the host is quickly re-colonised by zoospores released from exuvia after the moult (Oidtmann et al., 2002). Such re-colonisation may be enhanced by the fact that moulted crayfish usually stay in their shelter together with the old exoskeleton until their cuticle hardens (Mori et al., 2001). Whether the pathogen actually stays or immediately re-infects its host, the extent of colonised cuticle, and thus the pathogen detectability, is likely to be reduced after moulting.

Significant temporal trends in the proportion of confirmed pathogen carriers were only observed in the intermediately infected population (Pšovka). This might be related to differences in zoospore concentrations in the water. In the highly infected population (Smečno), not only the prevalence but also the average pathogen load per host is very high (Kozubíková, unpublished data). It is therefore likely that the zoospore concentration in this small pond is sufficient to ensure the rapid colonization of most crayfish hosts, and the pathogen prevalence remains high all the time. On the contrary, fewer crayfish seem to be infected in Pšovka and their parasite load is lower, which may reduce the efficiency of the pathogen to infect or re-infect hosts.

Our study suggests that the prevalence of crayfish infected with $A$. astaci may not be reliably determined by only one sampling, especially in the case of open, intermediately infected 
populations. To compare the prevalence of plague pathogen across various populations, crayfish should be obtained in the same season, preferably in spring before the main period of moulting. The lack of positive detection in material from one sampling date should never be interpreted as reliable evidence of a "plague-free" population.

Our study was only a pilot project, with one population of each infection level (very low, intermediate, high) included. These observed patterns should be therefore verified by future research focusing on factors influencing the temporal variation of $A$. astaci prevalence, and its relationship with the host population density.

\section{ACKNOWLEDGEMENTS}

This study was funded by the Grant Agency of Charles University (project No. 154110), the Czech Science Foundation (206/08/H049) and the Czech Ministry of Education (MSM0021620828 and LC06073). We thank Sara Cabanillas Resino for her help with performing the laboratory analyses, David Hardekopf for language corrections, and anonymous referees for comments on a previous version of the manuscript.

\section{REFERENCES}

Alderman D.J., 1996. Geographical spread of bacterial and fungal diseases of crustaceans. Rev. Sci. Tech. Off. Int. Epiz., 15, 603-632.

Aquiloni L., Martín M.P., Gherardi F. and Diéguez-Uribeondo J., 2011. The North American crayfish Procambarus clarkii is the carrier of the oomycete Aphanomyces astaci in Italy. Biol. Invasions, 13, 359-367.

Buřič M., Kouba A. and Kozák P., 2010a. Intra-sex dimorphism in crayfish females. Zoology, 113, 301-307.

Buřič M., Kouba A. and Kozák P., 2010b. Molting and growth in relation to form alternations in the male spiny-cheek crayfish. Orconectes limosus. Zool. Stud., 49, 28-38.

Cerenius L., Söderhäll K., Persson M. and Ajaxon R., 1988. The crayfish plague fungus Aphanomyces astaci - diagnosis, isolation, and pathobiology. Freshw. Crayfish, 7, 131-144.

Cerenius L., Bangyeekhun E., Keyser P., Söderhäll I. and Söderhäll K., 2003. Host prophenoloxidase expression in freshwater crayfish is linked to increased resistance to the crayfish plague fungus, Aphanomyces astaci. Cell. Microbiol., 5, 353-357.

Crawley M.J., 1993. GLIM for ecologists, Blackwell, Oxford, 379 p.

Crawley M.J., 2002. Statistical computing, Wiley, Chichester, 765 p.

Diéguez-Uribeondo J. and Söderhäll K., 1993. Procambarus clarkii Girard as a vector for the crayfish plague fungus, Aphanomyces astaci Schikora. Aquacult. Res., 24, 761-765.

Dunn J., McClymont H., Christmas M. and Dunn A., 2009. Competition and parasitism in the native white clawed crayfish (Austropotamobius pallipes) and the invasive signal crayfish (Pacifastacus leniusculus) in the UK. Biol. Invasions, 11, 315-324.

Ďuriš Z., Horká I. and Petrusek A., 2007. Invasive zebra mussel colonisation of invasive crayfish: a case study. Hydrobiologia, 590, 43-46.

Hochwimmer G., Tober R., Bibars-Reiter R., Licek E. and Steinborn R., 2009. Identification of two GH18 chitinase family genes and their use as targets for detection of the crayfish-plague oomycete Aphanomyces astaci. BMC Microbiol., 9, 184.

Holdich D. and Black J., 2007. The spiny-cheek crayfish, Orconectes limosus (Rafinesque, 1817) (Crustacea: Decapoda: Cambaridae), digs into the UK. Aquat. Invasions, 2, 1-16.

Holdich D.M., Reynolds J.D., Souty-Grosset C. and Sibley P.J., 2009. A review of the ever increasing threat to European crayfish from non-indigenous crayfish species. Knowl. Managt. Aquatic Ecosyst., 394-395, 11.

Johnsen S., Taugbøl T., Andersen O., Museth J. and Vrålstad T., 2007. The first record of the nonindigenous signal crayfish (Pasifastacus leniusculus) in Norway. Biol. Invasions, 9, 939-941.

Jones T.C. and Lester R.J.C., 1996. Factors influencing populations of the ectosymbiont Diceratocephala boschmai (Platyhelminthes; Temnocephalida), on the redclaw crayfish Cherax quadricarinatus maintained under laboratory conditions. Aquaculture, 143, 233-243. 
Kozubíková E., Petrusek A., Ďuriš Z., Kozák P., Geiger S., Hoffmann R. and Oidtmann B., 2006. The crayfish plague in the Czech Republic - review of recent suspect cases and a pilot detection study. Bull. Fr. Pêche Piscic., 380-381, 1313-1324.

Kozubíková E., Petrusek A., Ďuriš Z., Martin M.P., Diéguez-Uribeondo J. and Oidtmann B., 2008. The old menace is back: Recent crayfish plague outbreaks in the Czech Republic. Aquaculture, 274, 208-217.

Kozubíková E., Filipová L., Kozák P., Ďuriš Z., Martín M.P., Diéguez-Uribeondo J., Oidtmann B. and Petrusek A., 2009. Prevalence of the crayfish plague pathogen Aphanomyces astaci in invasive American crayfishes in the Czech Republic. Conserv. Biol., 23, 1204-1213.

Kozubíková E., Puky M., Kiszely P. and Petrusek A., 2010. Crayfish plague pathogen in invasive North American crayfish species in Hungary. J. Fish Dis. , 33, 925-929.

Lindqvist O.V. and Huner J.V., 1999. Life history characteristics of crayfish: What makes them good colonizers? In: Gherardi F. and Holdich D.M. (eds.), Crayfish in Europe as alien species - How to make the best of a bad situation?, A.A. Balkema, Rotterdam, 23-30.

Lowe S., Browne M., Boudjelas S. and de Poorter M., 2004. 100 of the world's worst invasive alien species. In: A selection from the Global Invasive Species Database, The Invasive Species Specialist Group (ISSG), a specialist group of the Species Survival Commission (SSC) of the IUCN, Gland, Switzerland.

Matthews M. and Reynolds J.D., 1990. Laboratory investigations of the pathogenicity of Aphanomyces astaci for Irish freshwater crayfish. Hydrobiologia, 203, 121-126.

Mori M., Pretoni Y., Salvidio S. and Balduzzi A., 2001. Branchiobdellid size-crayfish size: a possible relationship. J. Limnol., 60, 208-210.

Nylund V. and Westman K., 1983. Frequency of the visible symptoms of crayfish plague fungus Aphanomyces astaci on the American crayfish Pacifastacus leniusculus in natural populations in Finland. Freshw. Crayfish, 5, 277-283.

Nylund V. and Westman K., 2000. The prevalence of crayfish plague (Aphanomyces astaci) in two signal crayfish (Pacifastacus leniusculus) populations in Finland. J. Crust. Biol., 20, 777-785.

Oidtmann B., Cerenius L., Schmid I., Hoffmann R. and Söderhäll K., 1999. Crayfish plague epizootics in Germany - classification of two German isolates of the crayfish plague fungus Aphanomyces astaci by random amplification of polymorphic DNA. Dis. Aquat. Org., 35, 235-238.

Oidtmann B., Heitz E., Rogers D. and Hoffmann R.W., 2002. Transmission of crayfish plague. Dis. Aquat. Org., 52, 159-167.

Oidtmann B., Geiger S., Steinbauer P., Culas A. and Hoffmann R.W., 2006. Detection of Aphanomyces astaci in North American crayfish by polymerase chain reaction. Dis. Aquat. Org., 72, 53-64.

Persson M. and Söderhäll K., 1983. Pacifastacus leniusculus Dana and its resistance to the parasitic fungus Aphanomyces astaci Schikora. Freshw. Crayfish, 5, 292-298.

Petrusek A., Filipová L., Ďuriš Z., Horká I., Kozák P., Policar T., Štambergová M. and Kučera Z., 2006. Distribution of the invasive spiny-cheek crayfish (Orconectes limosus) in the Czech Republic. Past and present. Bull. Fr. Pêche Piscic., 380-381, 903-917.

Schulz H.K., Smietana P., Maiwald T., Oidtmann B. and Schulz R., 2006. Case studies on the cooccurrence of Astacus astacus (L.) and Orconectes limosus (Raf.): snapshots of a slow displacement. Freshw. Crayfish, 15, 212-219.

Skov C., Aarestrup K., Sivebæk F., Pedersen S., Vrålstad T. and Berg S., 2011. Non-indigenous signal crayfish (Pacifastacus leniusculus) are now common in Danish streams: preliminary status for national distribution and protective actions. Biol. Invasions, 13, 1269-1274.

Söderhäll K. and Cerenius L., 1999. The crayfish plague fungus: History and recent advances. Freshw. Crayfish, 12, 11-35.

Souty-Grosset C., Holdich D.M., Noël P.Y., Reynolds J. and Haffner P., 2006. Atlas of crayfish in Europe, Muséum national d'Histoire naturelle, Paris, $187 \mathrm{p}$.

Vey A., Söderhäll K. and Ajaxon R., 1983. Susceptibility of Orconectes limosus Raff. to the crayfish plague, Aphanomyces astaci Schikora. Freshw. Crayfish, 5, 284-291.

Vilá M., Basnou C., Gollasch S., Josefsson M., Pergl J. and Scalera R., 2009. One hundred of the most invasive alien species in Europe. In: Drake J.A. (ed.), DAISIE Handbook of alien species in Europe, Invading nature - Springer series in invasion ecology, 3, Springer: Dordrecht, The Netherlands, 265-268.

Vrålstad T., Knutsen A.K., Tengs T. and Holst-Jensen A., 2009. A quantitative TaqMan MGB real-time polymerase chain reaction based assay for detection of the causative agent of crayfish plague Aphanomyces astaci. Vet. Microbiol., 137, 146-155.

Westman K. and Savolainen R., 2001. Long term study of competition between two co-occurring crayfish species, the native Astacus astacus L. and the introduced Pacifastacus leniusculus Dana, in a Finnish lake. Bull. Fr. Pêche Piscic., 361, 613-627. 